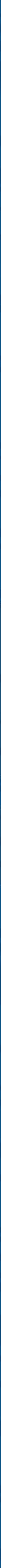




\section{Sumário}

I. Crônicas do Direito Internacional ...............................................1

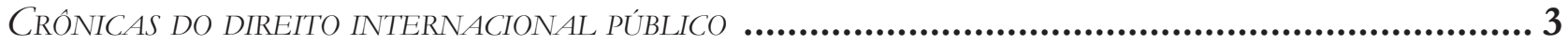

A resolução 2272 (2016) do Conselho de Segurança das Nações Unidas - O POSICIONAMENTO DA ONU FACE ÀS ALEGAÇÕES DE ABUSO E EXPLORAÇÃo SEXUAL POR SUAS

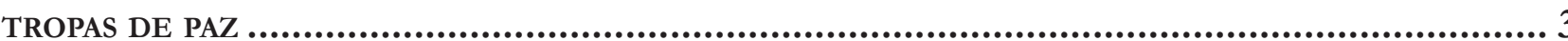

Sarah Dayanna Lacerda Martins Lima

CRÓNICAS DE DiREITo INTERNACIONAL PRIVADO...................................................................

Nadia de Araujo, Marcelo De Nardi, Gustavo Ribeiro, Fabrício Polido e Inez Lopes

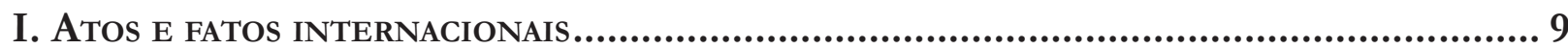

Crônica 1. Novidades de 2017 SObRE CIRCulaÇÃo faCilitada DE SENTENÇAS ESTRANGEIRAS 9

Crônica 2: O Direito Transnacional e os episódios das Carnes.........................................16

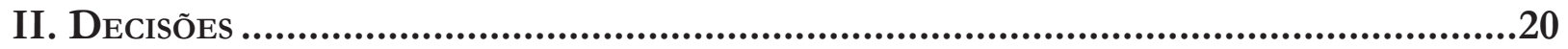

Crônica 3: A Irresistível ForÇa da ORDEM PÚblica E A HOMOLOGaÇÃo DE SENTENÇAS

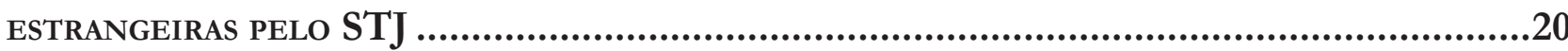

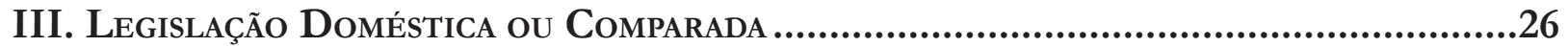

Crônica 4 - Dignidade da pessoa humana e mudança de paradigma da Lei de Migração

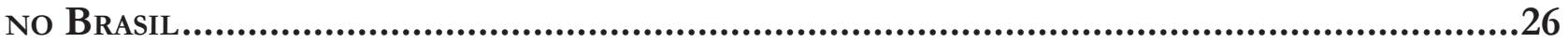

II. Dossiê especial: Direito Internacional dos InVEstimentos ................35

Non-adjudicatory State-State Mechanisms in Investment Dispute Prevention and Dispute Settlement: Joint Interpretations, Filters and Focal Points 
Mapping the Duties of Private Companies in International Investment Law .50 Nitish Monebhurrun

LA LÉGALITÉ DE L'INVESTISSEMENT DEVANT L'ARBITRE INTERNATIONAL: À LA RECHERCHE D'UN POINT D'ÉQUILIBRE .73 Hervé Ascensio

Host STATES AND STATE-STATE INVESTMENT ARBITRATION: STRATEGIES AND CHALlENGES......81 Murilo Otávio Lubamdo de Melo

Right to Regulate, Margin of Appreciation and Proportionality: Current Status in Investment Arbitration in Light of Philip Morris V. Uruguay. .95 Giovanni Zarra

Investments on Disputed Territory: Indispensable Parties and Indispensable Issues....122 Peter Tzeng

The Influence of General Exceptions on the Interpretation of National

Treatment in INTERNATIONAL INVESTMENT LAW. 140 Louis-Marie Chauvel

UMA PRoposta de REFleXão SObRe os ACFIs: Até QUE PONTO O TRATAMENTo de NAÇão MAIS FAVORECIDA PODE MINAR A ESTRATÉGIA POLÍTICA QUE OS EMBASA? 160

Michelle Ratton Sanchez Badin, Daniel Tavela Luis e Mario Alfredo de Oliveira

ECUADOR's 2017 TERMINATION OF TREATIES: HOW NOT TO EXIT THE INTERNATIONAL INVESTMENT REGIME 179

Jose Gustavo Prieto Muñoz

ONE BELT, ONE ROAD: NOVAS INTERFACES ENTRE O COMÉRCIO E OS INVESTIMENTOS INTERNACIONAIS 193

Flávio Marcelo Rodrigues Bruno e Marilda Rosado de Sá Ribeiro

III. Artigos Sobre outros TEMAS..................................................... 214

TolerânCIA E REFugIO: UM ENSAIO A PARTIR Do ACORdo EU-TurQUiA 216 Flávia Cristina Piovesan e Ana Carolina Lopes Olsen 
O TRATAMENTO do APÁtridA NA NOVA LEI DE MIGRAÇÃo: ENTRE AVANÇOS E RETROCESSOS...237 Jahyr-Philippe Bichara

O caráter humanista da Lei de Migrações: aVAnços da Lei N. 13.445/2017 E Os desafios DA REGULAMENTAÇÃO. 254 Marcelo Dias Varella, Clarice G. Oliveira, Mariana S.C. Oliveira e Adriana P. Ligiero

Reform of the United Nations Security Council: The Emperor Has No Clothes.268 Ljubo Runjic

A IDEIA DE QUe os LATINO-AMERICANOS PREFEREM O AUTORITARISMO À DEMOCRACIA À luz da reinterpretação dos Critérios do Programa das Nações Unidas para o DesenVolvimento 286

Gina Marcilio Pompeu e Ana Araújo Ximenes Teixeira

A PRoteção da ORIENTAÇÃo SEXUAL E IDENTIDAdE DE GÊNERO DIVERSAS NA CORTE PENAL internacional: Entre Realpolitiks E Os Direitos Humanos

Gustavo Bussmann Ferreira

A desnacionalização e as violações de direitos humanos na República Dominicana. 331 Daniela Menengoti Gonçalves Ribeiro e Rodrigo Ichikawa Claro Silva

CompetênCia do TPI no Caso do ATAque ao hospital de Kunduz: uma análise ENVOLVENDO A JURISDiÇÃo do TPI EM RELAÇÃO A NACIONAIS DE EsTAdOS NÃO-PARTE do Estatuto DE Roma

Filipe Augusto Silva e Renata Mantovani de Lima

A CRIMINALIZAÇÃo DOS IMIGRANTES EM SITUAÇÃo IRREGULAR NA ITÁliA: BIOPOLÍtica E DIREITO PENAL DO AUTOR.

Maiquel Angelo Dezordi Wermuth e Jeannine Tonetto de Aguiar

The New Rules On Trade And Environment Linkage In Preferential Trade Agreements

Alberto do Amaral Júnior e Alebe Linhares Mesquita

Beyond THE Border between the North and the South: towards a Decolonization of EPISTEMOLOGIES AND FIELDS OF RESEARCH ON MERCOSUR 
A aplicabilidade da Convenção de Montreal no direito brasileiro.

Aziz Tuffi Saliba e Alexandre Rodrigues de Souza

REgIME DE TRANSPARÊNCIA FISCAL NA TRIBUTAÇÃo DOS LUCROS AUFERIDOS NO EXTERIOR (CFC RULES): LACUNAS E CONFLITOS NO DIREITO BRASILEIRO

Paulo Rosenblatt e Rodrigo Torres Pimenta Cabral

As Regras Brasileiras de Tributação de Controladas e Coligadas no Exterior: verdadeiras Controlled Foreign Company (CFC) Rules? .......................................465

Melina de Souza Rocha Lukic e Amanda Almeida Muniz

O RETORNO DE BENS CULTURAIS

Aziz Saliba e Alice Lopes Fabris

Direitos culturais e Nações Unidas: uma análise a partir da Declaração Sobre a eliminação de Todas as Formas de Intolerância e Discriminação Baseadas na Religião OU NA CRENÇA

Leilane Serratine Grubba e Márcio Ricardo Staffen

OS REFLEXOS DA PROTEÇÃO INTERNACIONAL DA PROPRIEDADE INTELECTUAL PARA O DESENVOLVIMENTO INTERNO: UMA ANÁLISE SOBRE O SISTEMA PATENTÁRIO BRASILEIRO E A TRANSFERÊNCIA DE TECNOLOGIA

Michele M. Segala e Isabel Christine S. De Gregori

O CASO HIPOTÉTICO DA MORTE DO EMBAIXADOR FRANCÊS NA ESPANHA: DUAS ESPÉCIES DE IUS gentium em Francisco de Vitoria

Rafael Zelesco Barretto

De volta À BeVilaqua: anÁlise ECONÔMICA dA APLICAÇão do ART. $9^{\circ}$ DA LINDB Às OBRIGAÇÕES CIVIS CONTRATUAIS

Danielle Cristina Lanius e Ivo Teixeira Gico Jr 


\title{
Host states and state-state investment arbitration: strategies and challenges*
}

\section{Estado anftriões e arbitragem Estado- Estado: Estrategias e desafios}

Murilo Otávio Lubamdo de Melo**

\begin{abstract}
The article aims at discussing whether State-State arbitration in foreign investments is an available strategy to host States. It revises the language of investment treaty provisions and inter-state arbitral awards and then analyses cases and treaty-making practice. This article concludes that the possibility of State-State arbitration is not a backlash. It constitutes an additional opportunity for host States to advance their understanding of the treaties and to provide balance to investment treaty commitments. While State-State arbitration may be a viable strategy, there are some challenges that need to be overcome. The definition of the term dispute, the obligation to consult on the meaning of provisions and the establishment of a clear hierarchy between State-State awards in relation to investor-State awards are some of the ways forward.
\end{abstract}

Keywords: International Investment Law; State-State Arbitration; Investment Treaties; Host States; BITs.

\section{Resumo}

O artigo pretende discutir se a arbitragem Estado-Estado em matéria de investimentos internacionais é uma estratégia para os Estados anfitriões. Examina-se para tanto as provisões dos tratados de investimento e as sentenças arbitrais entre Estados e analisa-se casos e práticas de elaboração de tratados. Este artigo conclui que a possibilidade de arbitragem Estado-Estado não é uma adversidade. Constitui uma oportunidade adicional para os Estados anfitriões avançarem a sua compreensão dos tratados e proporcionarem mais equilíbrio aos compromissos dos tratados de investimento. Enquanto a arbitragem Estado-Estado pode ser uma estratégia viável, há alguns desafios que precisam ser superados. A definição do termo conflito, a obrigação de consultar sobre o significado das disposições e o estabelecimento de uma hierarquia clara entre as sentenças arbitrais Estado-Estado em relação às sentenças Estado-investidor são alguns dos os caminhos a seguir

Palavras-chave: Arbitragem Estado-Estado; Tratados dos investimentos; Estados anfitriões 


\section{INTRODUCTION}

The treatment of foreign investments and investors by host States may lead to conflicts of different nature. These conflicts may give rise to claims against regulations and individual decisions of the administrative entities of the government of the host State in domestic courts. The disputes may come up as claims related to the terms of investment contracts and agreements, brought by both the host State or the investor.

It is also widely recognised that international arbitration is an alternative for the resolution of these conflicts, provided there is consent expressed in any instrument. Bilateral investment treaties (BITs) have been the traditional way to provide such a consent, which is generally conferred by the treaty parties in relation to certain disputes arising under the terms of the treaty. ${ }^{1}$ An investor is then entitled to bring a claim against the host state, the so-called investor-state arbitration (ISA), based on BITs or, more generally, on international investment agreements, including trade agreements with an investment chapter (IIAs).

It is known that most part of the obligations in IIAs refer to the host States. They are responsible to guarantee the standards of treatment, with relation to foreign investors and their home States. Because of that, they are generally the respondents in the claims. ${ }^{2}$ On the other hand, the host state is not given the right to bring a claim against the investor based solely on the content of treaty, since it was the home State of the investor that signed up for the treaty obligations.

To understand this imbalance, the article analyses another type of mechanism to deal with this issue. It is the so-called State-State ${ }^{3}$ arbitration in foreign investments (SSIA). States, as repeat players in the international arena, have long-term relationship concerns; thus, when systemic interests come into play, the State-State path may be more attractive. The article discusses if it is an available strategy to host States under the current practice of international law. The chosen methodology is the description and analysis of treaty provisions,

1 For the classic argument, see Jan Paulsson, 'Arbitration Without Privity' (1995) 10 ICSID Review - Foreign Investment Law Journal 232.

2 See generally Giorgio Sacerdoti and others (eds), General Interests of Host States in International Investment Law (CUP 2014).

3 State-to-State or inter-state are also expressions related to the same concept. cases decided in international arbitrations and some hypothetical situations in order to conclude what are the available options for host States.

The theoretical and practical development of ISA meant that the debate around SSIA had been gradually forgotten. However, both the well-known shortcomings of ISA and the recurrent critiques against it ${ }^{4}$ suggest that a fresh analysis of the mechanism is required. Some State-State cases involving host States point out to a resurgence of the practice in the area. These are: Peru $v$ Chile $^{5}$ and Ecuador v United States. ${ }^{6}$ These cases sparked interest and were followed by a new range of academic contributors in this field. ${ }^{7}$ While these contributions

4 See, for example, UNCTAD, 'World Investment Report' (United Nations 2015) UNCTAD/WIR/2015 120-173.

5 Peru $v$ Chile arbitration related to the preliminary objections in the Empresas Lucchetti, S.A. and Lucchetti Peru, S.A. v The Republic of Peru, ICSID Case No. ARB/03/4

6 Republic of Ecuador v United States of America, PCA Case No 20125, Award, 29 September 2012, Available at http://www.italaw.com/ sites/default/files/case-documents/italaw7940.pdf

7 accessed 15 May 2017

Chang-fa Lo, 'Relations and Possible Interactions between StateState Dispute Settlement and Investor-State Arbitration under Bits' (2013) 6 Contemporary Asia Arbitration Journal 1; Michele Potestà, 'State-to-State Dispute Settlement Pursuant to Bilateral Investment Treaties: Is There Potential?' in Nerina Boschiero and others (eds), International Courts and the Development of International Law (T M C Asser Press 2013); Michele Potestà, 'Towards a Greater Role for Stateto-State Arbitration in the Architecture of Investment Treaties?' in Shaheeza Lalani and Rodrigo Polanco Lazo (eds), The Role of the State in Investor-State Arbitration (Brill 2014); Anthea Roberts, 'Stateto-State Investment Treaty Arbitration: A Hybrid Theory of Interdependent Rights and Shared Interpretive Authority' (2014) 55 Harvard International Law Journal 1; Clovis J Trevino, 'State-to-State Investment Treaty Arbitration and the Interplay with Investor-State Arbitration Under the Same Treaty' (2014) 5 Journal of International Dispute Settlement 199; Jarrod Wong, 'The Subversion of State-to-State Investment Treaty Arbitration' (2014) 53 Columbia Journal of Transnational Law 6; Nathalie Bernasconi-Osterwalder, 'State-State Dispute Settlement in Investment Treaties' (International Institute for Sustainable Development 2014) < http://www. iisd.org/sites/default/files/publications/best-practices-state-statedispute-settlement-investment-treaties.pdf $>$ accessed 23 July 2015; Anthea Roberts, 'Opinio Juris » Blog Archive HILJ Online Symposium: Anthea Roberts Responds to Martins Paparinskis - Opinio Juris' < http:/ /opiniojuris.org/2014/03/31/hilj-online-symposiumanthea-roberts-responds-martins-paparinskis/> accessed 16 May 2016; Martins Paparinskis, 'Opinio Juris » Blog Archive HILJ Online Symposium: On the Love of Hybrids and Technicalities - Opinio Juris' <http://opiniojuris.org/2014/03/31/hilj-online-symposiumlove-hybrids-technicalities/> accessed 16 May 2016; Matilde Recanati, 'Diplomatic Intervention and State-to-State Arbitration as Alternative Means for the Protection of Foreign Investments and Host States' General Interests: The Italian Experience' in Giorgio Sacerdoti and others (eds), General Interests of Host States in International Investment Law (CUP 2014); Giorgio Sacerdoti and Matilde Re- 
recognised the importance of SSIA, they have not yet analysed more carefully the strategies and challenges for the use of the mechanism from the point of view of the host States.

The article is structured in two parts, followed by a conclusion. The first part deals with concepts related to State-State arbitration and the general ways that host States could use this mechanism. The second part analyses the strategies and new approaches and explore further developments in the area.

\section{State-State investment arbitration}

\subsection{Jurisdictional Clauses}

It is widely recognised that the introduction of ISA has substituted to a large extent the recourse to diplomatic protection. ${ }^{8}$ This means that host States have been directly challenged by investors and home States have seen their role in arbitration progressively diminished. However, State-State dispute settlement mechanisms are still present in BITs and IIAs, though the recourse to this kind of arbitration has remained rare. ${ }^{?}$

In the current practice, a typical State-State clause in

canati, 'Approaches to Investment Protection outside of Specific International Investment Agreements and Investor-State Settlement' in Marc Bungenberg and others (eds), International Investment Law (Nomos ; Hart 2015); Theodore R Posner and Marguerite C Walter, 'The Abiding Role of State-State Engagement in the Resolution of Investor-State Disputes' in Jean E Kalicki and Anna Joubin-Bret (eds), Reshaping the Investor-State Dispute Settlement System: Journeys for the 21st Century (Brill Nijhoff 2015); María José Luque Macías, 'Looking Backwards to Inter-State Investment Dispute Settlement: Is There Space for Transparency?' (2016) forthcoming The Journal of World Investment \& Trade - Special Issue - The Latin American Challenge to the Current System of Investor-State Dispute Settlement; Murilo Lubambo, 'Is State-State Investment Arbitration an Old Option to Latin America?' (2016) 34(2) Conflict Resolution Quarterly 225; David Gaukrodger, 'State-to-State Dispute Settlement and the Interpretation of Investment Treaties' (Organisation for Economic Co-operation and Development 2016) OECD Working Papers on International Investment < http://www.oecd-ilibrary.org/content/ workingpaper/5jlr71rq1j30-en> accessed 1 October 2017.

8 Abmadou Sadio Diallo. (Republic of Guinea v Democratic Republic of the Congo) Preliminary Objections, Judgment 24 May 2007, ICJ Reports (2010) p. 36 para 88; CMS Gas Transmission Company (Claimant) and The Republic of Argentina (Respondent) Case No. ARB/01/8 Decision of the Tribunal on Objections to Jurisdiction para 45

9 Rudolf Dolzer and Christoph H Schreuer, Principles of International Investment Law (2nd ed, OUP 2012) 13. an IIA reads:

\section{Argentina-Quatar BIT (2016)}

ARTICLE 15 - Settlement of Disputes between the Contracting Parties

1. The two Contracting Parties shall strive with good faith and mutual cooperation to reach a fair and quick settlement of any dispute arising between them concerning interpretation or application of this Treaty. In this connection the two Contracting Parties hereby agree to enter into direct objective negotiations to reach such settlement.

If the disagreement has not been settled within a period of six months from the date on which the matter was raised by either Contracting Party, it may be submitted at the request of either Contracting Party to an Arbitral Tribunal composed of three members and under the UNCITRAL Arbitration Rules (2013), which shall apply except as otherwise mutually agreed by the disputing parties.

2. Within a period of two months from the date of receiving the said request each Contracting Party shall appoint one arbitrator, and the two arbitrators so appointed shall appoint within a period of three months and with the approval of both Contracting Parties the third arbitrator from a third country as Chairman of the Tribunal.

$\cdots$

6. It shall not be permitted to submit a dispute to an Arbitral Tribunal pursuant to the provisions of this Article, if the same dispute was submitted to another Arbitral Tribunal.

7. The Arbitral Tribunal shall rule on the basis of the provisions of this Treaty and of the rules and principles of International Law. The ruling of the Tribunal shall be by majority of votes. Such award shall be final and binding on both Contracting Parties. [emphasis added].

Therefore, in the terms of the provision, both treaty parties can submit the request for arbitration when an issue related to the interpretation or application of their treaty arises. This may arguably take place even if there is a pending arbitration brought by an investor against a host State. It will be submitted that a SSIA dispute will indeed have a different nature, and thus, will not be the same dispute.

Some comments can be made. First of all, if these clauses have persisted, they should not be considered as dysfunctional remainders of the old Friendship,

10 Signed on 06 November 2016. All IIAs and model BITs and all the investment decisions mentioned here are available at the UNCTAD database and Italaw respectively $<$ http://investmentpolicyhub.unctad.org/IIA > and < http://www.italaw.com > accessed 15 May 2017 
Commerce and Navigation treaties. ${ }^{11}$ They should be given meaning and purpose, for their very existence; otherwise they "would be rendered almost completely ineffective (an unacceptable result as a matter of treaty interpretation)." ${ }^{\prime 2}$

Second, it could be argued that apparently there is a narrower scope in an SSIA clause, which generally refers to the interpretation and/or application of the treaty, in comparison to the investor-State clause, which generally encompasses any dispute concerning an investment. ${ }^{13}$ However, it should be recognised that the clauses have generally an all-encompassing broad language ${ }^{14}$ with expression such as "any" or "a" dispute, with no specific qualifications. Therefore, it is to be accepted that text, object and purpose and history of BITs reveal that State-to-State arbitration should not be restricted in any way. ${ }^{15}$

Finally, it is to be stressed that the involvement of States in the correct interpretation of their investment treaties can always take place apart from State-State arbitration. However, these mechanisms will not be dealt here. ${ }^{16}$ Also, it is recognised that home States could also use SSIA as an alternative litigation strategy. ${ }^{17}$ As emphasised elsewhere:

\begin{abstract}
This is not a contention that SSIA is always a good substitute to ISA in terms of effectiveness to enforce investors' rights or in terms of protection of the sovereign right of host States. From a practical perspective, one could argue that if a treaty includes
\end{abstract}

11 For the historical use of SSIA and the development of jurisdiction clauses, see Kenneth J Vandevelde, Bilateral Investment Treaties: History, Policy and Interpretation (OUP 2010) 24-25; 504.

12 Martins Paparinskis, 'Investment Arbitration and the Law of Countermeasures' (2009) 79 British Yearbook of International Law 264, 296.

13 Vandevelde (n 11) 499. See, for example, the United States BIT Model (2012)

14 Roberts, 'State-to-State Investment Treaty Arbitration' (n 7) $6-7 ; 11-12$.

15 ibid 5.

16 See, in this regard, Wolfgang Alschner, 'The Return of the Home State and the Rise of "Embedded" Investor-State Arbitration' in Shaheeza Lalani and Rodrigo Polanco Lazo (eds), The Role of the State in Investor-State Arbitration (Brill 2014) 309-324; Tomoko Ishikawa, 'Keeping Interpretation In Investment Treaty Arbitration "on Track": The Role of State Parties' in Jean E Kalicki and Anna Joubin-Bret (eds), Reshaping the Investor-State Dispute Settlement System: Journeys for the 21st Century (Brill Nijhoff 2015).

17 That was the issue in Italy $v$ Cuba, Italian Republic $v$ Republic of Cuba, ad hoc State-State arbitration, Award 1 Jan 2008. Because it involved a claim by the home State in its use of diplomatic protection, this case is not analysed further. For details, see Michele Potestà, 'Republic of Italy v. Republic of Cuba' (2012) 106 AJIL 341. only the option of SSIA, the politically connected or economically robust companies would probably be the only ones able to convince the States to endorse their claims. The greater risk is for small and medium enterprises, which are less connected. Since they are the ones that should be benefiting from the investor-state system, a change to SSIA would not be more efficient for them. ${ }^{18}$

Nevertheless, the focus of this article is on how host States could effectively resort to SSIA as a defensive strategy and on what challenges they would face.

\subsection{Host States: SSIA as a "Shield"}

\subsubsection{State-State and Interpretative Claims}

It is time now to explore the possibility that host States resort to interpretive claims in the form of declaratory decisions. State-State arbitration under the jurisdictional clause in an IIA seems to be an adequate avenue for that. One could suggest that the request for a declaratory decision would be within the mandate of most SSIA jurisdiction clauses since this would involve elements of interpretation or application of the treaty. If an SSIA claim is brought by the host State, it will be a dispute between the host and home State related to the interpretation of a treaty provision and not a decision on whether the specific investor suffered a breach and should be entitled compensation.

International courts can be called upon to resolve merely interpretive questions, without claims of treaty violations and can recognise jurisdiction to make declaratory awards on the right interpretation of a provision. ${ }^{19}$ One might recall "the fundamental purpose of a declaratory judgment which is designed, in contentious proceedings involving a genuine dispute, to clarify and stabilize the legal relations of the parties", ${ }^{20}$ which would be the practical result of the issue. Thus, declaratory claims seem to be admissible for host States, so that

18 Lubambo (n 7) 229.

19 See Expert Opinion of Prof. Alain Pellet, Memorial, n 6 p. $15-$ 18, para 26-36 Citing among others ICJ Judgement, 27 August 1952, Rights of the National of the United States of American in Morocco (France v United States of America), ICJ Reports 1952, p. 179 and ICJ Judgement 13 July 2009, Dispute Regarding Navigational and Related Rights (Costa Rica v Nicaragua), ICJ Report 2009, p. 270-271 par. 156.

20 Nuclear Tests (Australia v France), Joint Dissenting Opinion of Judges Oneyama, Dillard, Jiménez de Aréchaga and Sir Humphrey Waldock, 20 December 1974, ICJ, ICJ Reports 1974, 321 (para 21). 
tribunals could be asked to adjudicate on interpretative issues. $^{21}$

But why would host States be interested in doing so? It is suggested that this could ensure that specific provisions are not given an interpretation that is divergent with the parties' intentions. This is especially relevant in face of the controversial interpretations by investor-State tribunals. Depending on how the consent to SSIA is framed and on whether there is a "dispute" with the other treaty party (the home State), this avenue may be promising. This is what one can draw from the Ecuador-United States litigation in the Permanent Court of Arbitration, to be commented later.

Of course, interpretive claims can also be used by home States. To illustrate, the conflict that resulted in the arbitration between $B C B v$ Belize $e^{22}$ could have involved a State-State arbitration pursuant to the United Kingdom (UK)-Belize BIT. The mechanism was an extra tool to make the investor State arbitration effective, with a declaratory decision on the meaning of a BIT provision. ${ }^{23}$ In the specific case, an interpretative claim was cogitated by the UK to check the interpretation of a specific BIT provision. Both Belize and the UK would have had already expressed their views, so the existence of a "dispute" would not be a problem. ${ }^{24}$ Anyway, a broad definition by the parties in their treaties of the term "dispute" would be the natural solution to enlarge the role of SSIA ${ }^{25}$, especially for host States.

21 See Gaukrodger (n 7) 28-31. which brings the example of Kyrgyzstan's request for the interpretation of the Moscow Convention, in the context several ISA claims against that host State.

22 British Caribbean Bank Limited v. The Government of Belize, UNCITRAL, Award (19 December 2014), PCA Case No. 2010-18, 23 Posner and Walter (n 7) 387-388. See also Luke Eric Peterson, "Spectre of State-to-State claim recedes as Belize makes peace with investor-State proceeding (and some transparency)" Sep 30, 2013 | by <http://www.iareporter.com/articles/spectre-of-state-to-stateclaim-recedes-as-belize-makes-peace-with-investor-state-proceeding-and-some-transparency/ > accessed 1 October 2017

24 Peterson ibid “... [i] t might have fallen to the United Kingdom to determine whether it took a different view as to the interpretation to be given to the investor-state arbitration mechanism of the UK-Belize BIT. If the UK wished to push such an alternative interpretation, it would have enjoyed the ability to initiate a state-to-state arbitration with Belize, pursuant to Article 9 of the BIT, in order to seek a determination of a dispute over the 'interpretation or application' of the BIT.... [t] he UK-Belize controversy might have presented $a$ more clear-cut dispute given that both sides would have presumably weighed in with differing views as to whether the investor-state provisions of the treaty are subject to a ripeness or even an exhaustion requirement." emphasis added

25 Bernasconi-Osterwalder (n 7) 21.

\subsubsection{Relation between SSIA and ISA}

These types of claims bring the issue of the relation between State-State arbitration and investor-State, especially the possible binding effect of the former on the latter. It is important to recall that international law does not exclude conflict of rules nor does it prohibit States from undertaking conflicting obligations, but courts have applied techniques of general international law to dismiss conflict. ${ }^{26}$ The answer would naturally depend on several aspects, such as whether the SSIA takes place after, parallely or before an ISA proceeding and obviously on the subject matter of the proceedings.

In this regard, the academic literature varies. One might argue that there is binding effect with regard to the interpretation of treaty provisions from SSIA in relation to future investor-State tribunals. ${ }^{27}$ Another contention would be to accept this last conclusion, unless the "interstate interpretation is manifestly incompatible or irreconcilable with the treaty text and/or the treaty parties' intended meaning". ${ }^{28}$ Some suggest that the effects of res judicata would be a better approach to the matter. ${ }^{29}$ Others propose relying on the good faith principle to solve conflicts between parallel or successive arbitration proceedings, especially for the last tribunal to be called upon; ${ }^{30}$ this seems to suggest the "priority of the court first seised" or an adoption of "the principle of priority in time". ${ }^{31}$

Finally, one takes note of the controversial claim that SSIA should be always precluded whenever there is an investment treaty containing an investor-State clause with jurisdiction to deal with the issue, regardless of whether consent to it has been perfected. ${ }^{32}$ This would

26 James Crawford and Penelope Nevill, 'Relations between International Courts and Tribunals: The "Regime Problem", Regime Interaction in International Law (CUP 2012) 236-237.

27 Potestà, 'Towards a Greater Role for State-to-State Arbitration in the Architecture of Investment Treaties?' (n 7 ) 270-272. Cf. Potestà, 'State-to-State Dispute Settlement Pursuant to Bilateral Investment Treaties' (n 7) 762. See also Broches opinion in ICSID, Convention on the Settlement of Investment Disputes between States and $\mathrm{Na}$ tionals of Other States (International Centre for Settlement of Investment Disputes 1968) 350. "[T]he Tribunal constituted under the Convention would regard itself as bound by the decision under the bilateral agreement, to the extent that the interpretation of that agreement had a bearing on the case before it."

28 Trevino (n 7) 232.

29 Paparinskis (n 7).

30 Lo (n 7) 15-21.

31 Crawford and Nevill (n 26) 244.

32 Wong (n 7) 31-37. 
go against the principle of effectiveness of the jurisdiction clause. In this regard, Berman comments that "the idea of there being a parallel State-to-State forum for sorting out problems, which as foreseen from the outset alongside the investor-to-State system is something which is available, should be available, might be more available in the future..." 33 Thus, one should conclude that SSIA is not merely subsidiary to ISA.

This contribution does not aim to give definite answers. But, considering an express delegation of interpretive powers by the parties to the State-State tribunals, ${ }^{34}$ few would deny that a previous State-State arbitration decision, which interprets a specific provision in a treaty, should be, at least, highly persuasive to future investor-State tribunals dealing with the same subject matter. This is because it would be very difficult to ignore the interpretation made by a tribunal, the adjudicatory authority of which is based exactly on a jurisdictional clause to interpret the treaty. This enhances the value of a State-State arbitration ignited by the host State, as an effective litigation strategy.

\subsubsection{Declaratory Claims of Non-Breach}

Another option one could think for the host State is to resort to declaratory claims of non-breach or of limited breach. This means seeking a declaration that a host State measure is fully or partially consistent with its obligations under a treaty. In this regard, Roberts ponders whether a host State could ask for a declaration of non-violation of the treaty and, by pre-emption, avoid investor-State claims or force them to be solved on a class-wide basis. ${ }^{35}$ Imagine that a state desires to edit a new law establishing an obligation for companies to keep a substantially larger area of native forests along the river margins and the coastal areas. They may desire to make sure that this will not be considered indirect expropriation of foreign investment developments in

33 Berman (n 19) 72 emphasis added."page":"67-72; 82","source":"catalogue.ulrls.lon.ac.uk Library Catalog","'eventplace":"London","ISBN":"978-1-905221-08-0","callnumber":’TCD PL-471-275","'collection-editor":[\{“family":’'Ort ino","'given":,'Federico"'\}],"editor":[\{“literal":'”British Institute of International and Comparative Law" $\}]$,"author":[[ “family":,Berma n","given":'Frank"\}],"issued":\{“date-parts":[[“2007”]]\}\},"locator" :"72","suffix":"'added emphasis"'\}],"schema":"https://github.com/ citation-style-language/schema/raw/master/csl-citation.json"\}

34 Anthea Roberts, 'Power and Persuasion in Investment Treaty Interpretation: The Dual Role of States' (2010) 104 AJIL 179, 225.

35 Roberts, 'State-to-State Investment Treaty Arbitration' (n 7) 10. those areas, which would be in breach of an IIA clause.

Due to the lack of case law regarding this type of claims, some have expressed concerns especially questioning the scope of the SSIA provision. ${ }^{36}$ But there seems to be some room to the contention that the host State is entitled to make such a request for a declaratory award of non-breach. Some arguments are presented, without intending to close the issue.

First of all, this would be indeed an application of treaty provisions to a set of facts, therefore, generally included in the jurisdiction of State-State tribunals. The request is for the tribunal to analyse whether or not facts or conducts fall under treaty rules. Of course, the host State will run the risk of receiving a non-wanted response.

Second, a declaratory judgment is not always to be considered a form of satisfaction, therefore, requiring an international wrongful act. ${ }^{37}$ Its nature is more linked to the judicial act itself, in order to solve a wide variety of disputes. ${ }^{38}$ In several cases, the World Court had to declare rights without referring to a breach or violation, thus, not ruling on issues of responsibility. ${ }^{39}$

Third, both host and home States would be bound by the non-breach decision rendered by a SSIA tribunal. At least, the home State would be under an obligation of good faith not to frustrate the declaratory decision. This possibly makes it incapable of offering diplomatic protection based on the measure or prohibited to actively encourage its nationals to seek international treaty-based arbitration.

Finally, the request for a declaration of non-breach, with its resulting consequences, is what respondent States would seek by using counterclaims. Judicial economy and guarantee of consistency are among the rationale for recognising counterclaims. ${ }^{40}$ Provided that some criteria are fulfilled (jurisdiction of the court and direct

36 Bernasconi-Osterwalder (n 7) 14.

37 Eric Wyler and Alan Papaux, 'The Different Forms of Reparation: Satisfaction' in James Crawford, Alain Pellet and Simon Olleson (eds), The law of international responsibility (OUP 2010).

38 Juliette McIntyre, 'Declaratory Judgments of the International Court of Justice', Hague Yearbook of International Law (Martinus Nijhoff 2012) 156.

39 Right of Passage over Indian Territory (Portugal v India), 12 April 1960, ICJ, Merits, ICJ Reports 1960; Dispute regarding Navigational and Related Rights (Costa Rica v Nicaragua), 13 July 2009, ICJ, Judgment, ICJ Reports 2009, 269-272, para 156.

40 Constantine Antonopoulos, Counterclaims before the International Court of Justice (TMC Asser Press 2011) 57-59. 
connection to the subject of the main claim) ${ }^{41}$ courts have been entertaining counterclaims. ${ }^{42}$ Thus, why not accept them as claims at the beginning? It is true that a counterclaim is not a defence on the merit, but requires something "more" in the form of a judgement against the applicant, but it is an alternative to deprive a main claim of force and mitigate its adverse character. ${ }^{43}$

Anyway, it is in the binding effect of the declaration on future investor-State tribunals where the problem lies. While it is difficult to accept that it would pre-empt future tribunals, it is submitted that the decision should certainly be highly persuasive on them.

\section{New Strategies AND APPROACHES}

\subsection{Strategies for Host States}

There are State-State provisions in virtually all of BITs and other agreements with investment provisions. ${ }^{44}$ As seen above, these clauses are more than present and need to be given meaning and purpose. This is not a contention that SSIA is a good substitute to a competent defence in an ISA in terms of effectiveness to the protection of the sovereign right of host States. SSIA can be useful to the host State on its own or as complement to ISA.

As an example, the first attempt of coordination between ISA and SSIA proceedings took place in Empresa Luchetti v Peru referred to Peru v Chile. ${ }^{45}$ It was, for some time, the only State-State dispute under a BIT. The underlying rationale of the case seemed to accept the principle of an exclusive mandate for each constituted tribunal, where no coordination at all is attempted. ${ }^{46}$ The investor's tribunal denied the request for suspension made by the host State (Peru), which had submitted an arbitration against the home State (Chile) regarding the interpretation of the BIT; but, in the end, the investor's tribunal dismissed the claim for lack of

\footnotetext{
41 According to Rule 80(1) of the ICJ Rules of the Court.

42 Antonopoulos (n 40) 73-134.

43 ibid 60; 63.

44 See < http://investmentpolicyhub.unctad.org/IIA > accessed 15 May 2017

45 See $n 5$

46 Crawford and Nevill (n 26) 237-239.
}

jurisdiction. ${ }^{47}$ An opposite approach would be the option for coordination, which would be the result of the application of the general principle of cooperation, by showing jurisdictional deference to the SSIA, which did not happen. ${ }^{48}$

To illustrate the strategies for host States, one could reflect on the outcome of litigations such as those related to Argentinian crisis. Several of those cases affected US investors and suffered from a lack of consistency. ${ }^{49}$ The question is how it would be different in the case of the existence of a binding interpretation made by an SSIA tribunal, previous to the ISA tribunals. The interpretation could relate to controversial BIT provisions or to the interplay between customary international and treaty law, for example.

In the context of the Argentina-US BIT, it is worth exploring how both home and host States could have used the State-State arbitration. The relevant clauses are the following:

\section{ARTICLE VI}

The Parties agree to consult promptly, on the request of either, to resolve any disputes in connection with the Treaty, or to discuss any matter relating to the interpretation or application of the Treaty.

$\cdots$

\section{ARTICLE VIII}

1. Any dispute between the Parties concerning the interpretation or application of the Treaty which is not resolved through consultations or other diplomatic channels, shall be submitted, upon the request of either Party, to an arbitral tribunal for binding decision in accordance with the applicable rules of international law. In the absence of an agreement by the Parties to the contrary, the arbitration rules of the United Nations Commission on International Trade Law (UNCITRAL), except to the extent modified by the Parties or by the arbitrators, shall govern.

47 See Empresas Luchetti n 5 362: "Respondent filed a request for suspension of the proceedings, in view of the fact that 'Claimants' Request for Arbitration [was] (...) the subject of a concurrent Stateto-State dispute between the Republic of Peru and the Republic of Chile.' ... [T] he Tribunal found that the conditions for a suspension of the proceedings were not met and confirmed the schedule for the submission of pleadings on the objections to jurisdiction."

48 Crawford and Nevill (n 26) 242-243.

49 For an analysis on the lack of consistency and its consequences on legitimacy, see William W Burke-White, 'Argentine Financial Crisis: State Liability under BITs and the Legitimacy of the ICSID System, The' (2008) 3 Asian Journal of W'TO and International Health Law and Policy 199. 
It seems legally possible that Argentina, as a host State, could have initiated an interpretative claim against the United States to provide legal certainty to its defence. The objective would be to obtain a clearer interpretation of a contentious provision, most probably to its own benefit. This would have ensured more consistent results in the investor-State claims. There seems to be compelling arguments to sustain this position.

In this regard, the Ecuador v US case $^{50}$ is illustrative. Ecuador brought a claim against the United States for the interpretation of Article II(7) of the US-Ecuador BIT, which dealt the 'effective means' obligation. The same provision was one the contested issues of a pending investor-State arbitration brought by an American investor against Ecuador. The United States had not responded to Ecuador's initiative to discuss the content of the provision. It seems that the silence of the United States with the regard to Ecuador`s request for interpretation of the article and the communication that it would not manifest at all on the matter ${ }^{51}$ could be interpreted as inaction. This would amount to holding "opposing views", thereby creating a dispute. ${ }^{52}$

However, the majority of the tribunal was not fully convinced and denied jurisdiction for the inexistence of a dispute. Claiming that the recourse to SSIA was void of practical consequences and could jeopardise the effectiveness of ISA, the majority argued that:

... the United States could directly allege a breach
of the 'effective means' obligation in Article II(7)
against Ecuador, in which case there would be clear
'practical consequences' for both Parties. ... [S]
ome commentators consider that recourse to State-
to-State dispute resolution for breaches of a BIT
may be possible, in particular where the investment
dispute in question has not already been submitted
to investor-State arbitration under Article VI. The
Tribunal makes no finding on this point, but is not
persuaded to exclude this possibility outright.

One interpretation was that the award was a conscious application of a technique described as a restrictive interpretation of a 'dispute' for the purposes of a

50 See 6

51 See n 6 Witness Statement of Mr. Luis Benigno Gallegos

52 See n 6 Expert Opinion Pellet, McCaffrey and Amerasinghe generally citing Land and Maritime Boundary between Cameroon and Nigeria (Cameroon v Nigeria), Preliminary Objections, Judgment, ICJ Reports 1998, p. 315, para 89 and Application of the Convention on the Elimination of All forms of Racial Discrimination (Georgia v Russia), Preliminary Objections, ICJ Judgement, 1 Paril 2011, ICJ Reports 2011, p. 16, para 30 treaty. ${ }^{53}$ Therefore, a broader definition of dispute in the SSIA context within the treaty could be useful, as suggested above. Note, though, that the majority did not exclude the possibility of recourse to SSIA for BIT breaches. The dissenter considered that silence represents a dispute in the following terms:

The myth of judicializing diplomacy in resorting to arbitration in order to settle a dispute underestimates the dispute settlement system which, in this case, is activated by the reluctance of one of the Parties to acknowledge a dispute and the frustration of prospective negotiations as the primary method to reach an agreement acceptable to both Parties. Therefore, the interpretation made by an arbitral tribunal constituted under Article VII will neither jeopardise nor undermine the arbitration mechanism between investors and States set forth in Article VI. On the other hand, it is difficult to understand how recourse to arbitration will politicise investment disputes between investors and States, where the purpose of arbitration is to interpret a treaty rule according to what the parties regarded is its content and scope, thus ensuring the necessary credibility of the system by clarifying the law in force, as the Parties stated at the time of expressing their consent to be bound. ${ }^{54}$

Since the decision has been extensively discussed and commented elsewhere, ${ }^{55}$ the focus is on one argument raised by Ecuador, which deserves attention. Considering that most IIAs have provisions on the obligation to consult (art. VI in the US-Argentina BIT), the refusal to do so is a breach of the treaty. It is submitted that an interpretation of the tribunal of the provision that was the aim of the consultations can be considered proper satisfaction, a form of reparation under international law, appropriate to put an end to the violation. ${ }^{56}$ This path can be explored, provided that the parties show evidence that the claimant made every effort to consult. A clearer language in this line can be noticed in article 15.1 of the recent Argentina-Qatar BIT reproduced above: parties are obliged to engage in good faith direct negotiations regarding the interpretation of provisions of the treaty.

53 Crawford and Nevill (n 26) 241.

54 Republic of Ecuador $v$ United States of America, PCA Case No 2012-5, Dissenting Opinion of Prof. Raúl Emilio Vinuesa, 29 September 2012 Available at < http://www.italaw.com/sites/default/ files/case-documents/italaw7942_0.pdf > accessed 15 May 2017

55 See, for example, Marcin Orecki, 'State-to-State Arbitration pursuant to Bilateral Investment Treaties: The Ecuador-US Dispute.' < http:/ / www.youngicca-blog.com/state-to-state-arbitrationpursuant-to-bilateral-investment-treaties-the-ecuador-us-dispute/> accessed 16 May 2015; Bernasconi-Osterwalder (n 7) 11-14; Roberts, 'State-to-State Investment Treaty Arbitration' (n 7) 10-16.

56 Pellet, Expert Report (n 19) 18 
Thus, it is convincing to think that Argentina could have initiated consultations with the United States to provide a binding interpretation of treaty provisions. In case of disagreement, it could bring a State-State interpretive claim. ${ }^{57}$ Anyway, it has been reported that the country at least envisaged such possibility to bring clarity and coherence to divergent interpretation of its cases. ${ }^{58}$ As sustained elsewhere:

In fact, the criteria for using the state-state jurisdictional clause as a defense are not clear. This may explain why it has not been used more extensively. The unsuccessful attempts appear to be due more to the specificities of the cases than to an impossibility of using the clause that way. ${ }^{59}$

Moreover, there are reasonable arguments for another possibility. Argentina, as a host State, could have brought a declaratory claim that it was not liable, claiming there had been no treaty violations. For example, Argentina could have requested a State-State arbitration asking for the court for a declaration that the measures taken after the Argentinian crisis were taken in accordance with art. XI of the BIT with the United States; therefore, they were necessary to protect its essential security interests. On the other hand, one might doubt that Argentina could have prevented all the investor-State claims with this initiative.

Finally, as to the enforcement pressure against Argentina due to the non-payment of its awards, measures characterised as retorsion were carried out, but none reached a State-State phase. ${ }^{60}$ In the aftermath of the discussion, Argentina 's position was in favour of the use of State-State arbitration. In the ICSID context, this means using

57 Cf Roberts, 'State-to-State Investment Treaty Arbitration' (n 7) 4 .

58 "Argentine Republic officials have deliberated for some time as to whether to seek state-to-state arbitration ... it would seem unlikely that the Republic would be dissuaded from pursuing state-to-state arbitration merely on the basis of the failure of Ecuador's efforts. ...." As reported inn Luke Eric Peterson, 'United States defeats Ecuador's state-to-state arbitration; will outcome dissuade Argentine copycat case?' (IAReporter, 2 September 2012) < http://www. iareporter.com/articles/united-States-defeats-ecuadors-state-tostate-arbitration-will-outcome-dissuade-argentine-copycat-case/ > accessed 15 May 2017.

59 Lubambo (n 7) 239.

60 Brooks E Allen and Tommaso Soave, 'Jurisdictional Overlap in WTO Dispute Settlement and Investment Arbitration' in Jorge A Huerta-Goldman, Antoine Romanetti and Franz X Stirnimann (eds), WTO Litigation, Investment Arbitration and Commercial Arbitration (Kluwer Law International 2013) 379-381; Catharine Titi, 'Investment Arbitration in Latin America' (2014) 30 Arbitration International 357, 369-377. art. 64 of the Convention, which fulfils the consent to grant jurisdiction to the International Court of Justice ICJ. The result would be a decision of the ICJ, ruling that the State has or has not violated its obligations under art. 53 of the ICSID Convention. Argentina recalled art. 64, indicating that the ICJ was the appropriate forum to discuss non-enforcement of awards. ${ }^{61}$ Nevertheless, to date, though, this option has not been used. ${ }^{62}$ As another example, it could be mentioned that in a demand related to its sovereign debts, Argentina tried to sue the US in the ICJ claiming violations of its sovereignty and immunities in relation to decisions of US Courts. The US refused to accept jurisdiction. ${ }^{63}$

\subsection{New Approaches for Host States}

Coming to the end of the article, it is worth commenting on new treaty-making approaches. It is important to emphasise that a reaction against ISA or a traditional stance against it does not mean disengagement with international investment law. As an illustrative point, South American States have reached an advanced level of the negotiations towards the constitution of a centre for the settlement of disputes, a process initiated in 2008, under the umbrella of UNASUR.$^{64}$ UNASUR regional initiative came in line with withdrawals from ICSID and as a political reaction against the outcomes of the system. ${ }^{65}$ This may bring a new arena to decide on or settle disputes involving investors or States of the region and outside it. In this regard, one might notice the likelihood of the inclusion of SSIA in the UNASUR Centre. ${ }^{66}$ However, the potential of the UNASUR Centre will only be real if it is given jurisdiction progressively, ${ }^{67}$ by means of consent in investment agreements

61 Posner and Walter (n 7) 388; Titi (n 60) 374.

62 Allen and Soave (n 60) 380.

63 See <http://www.icj-cij.org/presscom/files/4/18354.pdf >

64 For details about the BIT practice of South American countries, see Magdalena Bas, 'América do Sul em face dos tratados bilaterais de investimento: rumo ao retorno do Estado na solução de controvérsias?' (2016) 13 Revista de Direito Internacional (Brazilian Journal of International Law) <https://www.publicacoesacademicas.uniceub.br/rdi/article/view/3944> accessed 1 October 2017.

65 Omar E García-Bolívar, 'Permanent Investment Tribunals: The Momentum Is Building Up' in Jean E Kalicki and Anna JoubinBret (eds), Reshaping the Investor-State Dispute Settlement System: Journeys for the 21st Century (Brill Nijhoff 2015) 396; 399.

66 Available at < http://www.andes.info.ec/es/noticias/expertos-unasur-ultiman-detalles-creacion-tribunal-o-comision-solucioncontroversias.html > accessed 15 May 2017.

67 García-Bolívar (n 65) 402. 
or contracts, for subsequent disputes.

The dispute settlement mechanism of the new investment treaty model of Brazil merits discussion. The model resulted in treaties signed with Angola, Mozambique and Malawi in Africa and Mexico, Chile, Colombia and Peru in Latin America. ${ }^{68}$ Most recently, MERCOSUR members signed an intra-bloc treaty, the Protocol of Cooperation and Facilitation of Investments. ${ }^{69}$ The new treaties have constituted a political compromise that seek to maintain coherence with the traditional policy discourse in Brazil against ISA. ${ }^{70}$ The treaties have been the focus of some academic analysis, especially in relation to its standards and novelties. ${ }^{71}$ However, what interests most here are the mechanisms for dispute settlement.

Unlike the treaties signed with the African States, which refer only to the possibility of future development of SSIA, the treaties signed by Brazil with the Latin American States contain consent by the parties to SSIA. In this regard, the provisions of the Brazil-Mexico BIT are the following:

Artículo 19

Solución de Controversias entre las Partes

1. Cualquiera de las Partes podrá recurrir al arbitraje entre los Estados, una vez que se haya agotado el procedimiento previsto en el párrafo 3 del Artículo 18 sin que la disputa haya sido resuelta.

2. El objetivo del arbitraje es poner en conformidad con el presente Acuerdo la medida eventualmente declarada como disconforme al mismo por el laudo arbitral. Las Partes, sin embargo, podrán acordar que los árbitros examinen la existencia de perjuicios causados por la medida cuestionada y establezcan por medio del

68 See <http://www.itamaraty.gov.br/index.php?option=com_ content\&view $=$ article \&id $=9890$ :acordo-brasil-mexico-de-cooperacao-e-facilitacao-de-investimentos-cidade-do-mexico-26-demaio-de-2015\&catid $=42 \&$ Itemid $=280 \&$ lang $=$ pt-BR $>$ accessed 15 May 2017.

69 See < <ttp://www.itamaraty.gov.br/pt-BR/notas-aimprensa/16067-protocolo-de-cooperacao-e-facilitacao-de-investimentos-do-mercosul-pcfi > accessed 15 May 2017.

70 For a general description of the Brazilian policy, see Daniel de Andrade Levy, Ana Gerdau de Borja and Adriana Pucci (eds), Investment Protection in Brazil (Kluwer Law International 2014).

71 Nitish Monebhurrun, Novelty in International Investment Law: The Brazilian Agreement on Cooperation and Facilitation of Investments as a Different International Investment Agreement Model' [2016] Journal of International Dispute Settlement; Catharine Titi, 'International Investment Law and the Protection of Foreign Investment in Brazil' Transnational Dispute Management $<$ http:/ /www.transnational-dispute-management.com/journal-advance-publication-article.asp?key=592> accessed 15 May 2015. laudo, una indemnización por dichos perjuicios. Si el laudo arbitral establece una compensación monetaria, la Parte que recibe tal indemnización deberá transferirla a los titulares de los derechos de la inversión en cuestión, una vez deducidos los costos de la controversia, de conformidad con los procedimientos internos de cada Parte.

3. Este Artículo no se aplicará a ninguna controversia que haya surgido ni a ninguna medida que haya sido adoptada antes de la fecha de entrada en vigor del presente Acuerdo.

4. Las Partes podrán constituir un tribunal arbitral específico para la controversia de conformidad con el párrafo 5 de este Artículo, u optar, conjuntamente, por someter la controversia a otro mecanismo para solución de controversias entre Estados en materia de inversiones.

8. El tribunal arbitral determinará su propio procedimiento y tomará su decisión por mayoría de votos. Tal decisión será obligatoria para ambas Partes. A menos que se acuerde de otra manera, la decisión del tribunal arbitral deberá dictarse dentro de los seis (6) meses siguientes a la designación del Presidente, de conformidad con los párrafos 4 y 5 de este Artículo.

In the same line, it is worth transcribing below some parts of the respective provision in the Investment Chapter of the Brazil-Peru Economic and Trade Expansion Agreement, signed in April 2016:

Artigo 2.21: Solução de Controvérsias entre as Partes

1. Qualquer uma das Partes poderá recorrer a mecanismos de arbitragem entre os Estados, desde que tenha esgotado o procedimento previsto no artigo 2.20.3 (Consultas e Negociações Diretas) sem que a controvérsia tenha sido resolvida.

2. O objetivo da arbitragem entre os Estados é colocar em conformidade com o Capítulo a medida declarada incompativel com o Capitulo pelo laudo arbitral.

3. Não poderão ser objeto de arbitragem os artigos 2.12 (Investimento e Medidas sobre Saúde, Meio Ambiente e outros Objetivos Regulatórios em Matéria Social); 2.13 (Responsabilidade Social Corporativa); e 2.14 (Medidas sobre Investimento e Luta contra a Corrupção e a Ilegalidade).

4. Nenhuma reclamação poderá ser submetida ao mecanismo previsto neste Artigo, se tiver transcorrido um prazo maior que cinco anos contados a partir da data em que o investidor teve pela primeira vez ou deveria ter tido conhecimento pela primeira vez de uma alegada violação deste Acordo.

5. O Tribunal Arbitral será constituído em conformidade com o parágrafo 6 deste artigo. Não obstante, as Partes poderão decidir conjuntamente submeter a controvérsia a uma instituição arbitral 
permanente para a solução de controvérsias entre Estados relativas a investimentos.

10. O tribunal arbitral determinará seu próprio procedimento. O tribunal arbitral tomará sua decisão por maioria de votos. Tal decisão será obrigatória para ambas as Partes. A menos que as Partes decidam algo distinto, o laudo do tribunal arbitral deverá ser prolatado dentro dos seis meses seguintes à designação do Presidente de acordo com os parágrafos (6) e (7).

First of all, it is to be noted that the dispute settlement provisions of the treaties focus primarily on dispute prevention (Brazil-Mexico BIT, art. 18 and Brazil-Peru Chapter, art. 2.20). ${ }^{72}$ This was highlighted in the context of revision of treaty-making practice as an alternative model. ${ }^{73} \mathrm{~A}$ traditional system of consultations between the parties is available with regard to the interpretation and application of the treaty in relation to specific measure affecting an investor. The difference is that the investor will take part in the proceedings, providing information and attending the consultation meetings. A final opinion on the dispute by each of the parties is to be issued at the end of the consultation proceedings.

Secondly, the result of the consultations will base the SSIA claim, which can take the form of declaratory claims in relation to the compatibility of a general or more concrete measure affecting an investor (Brazil-Mexico BIT, art. 19(2) and Brazil-Peru, art. 2.21(2)). ${ }^{74}$ In this regard, the available remedy within the mandate of the tribunal will be the declaration of the conformity of the measure with the treaty. But this is not equivalent to an order for withdrawal or change of the measure. On the other hand, it is not clear whether questions of mere interpretation of the treaties will be under the jurisdiction of the SSIA clause, absent a concrete affected investor. However, one can presume that they are included, based on the reading of some provisions (Brazil-Mexico BIT, art. 14(4)f and Brazil-Peru Chapter, art. 2.15(4)g $)^{75}$, provided that the respective Joint Committees have previously addressed the matter or agreed on the request.

Finally, there are effective mechanisms to ensure

72 See also Art. 22 of the Brazil-Colombia IIA and Art. 24 of the Brazil-Chile IIA.

73 UNCTAD (n 4) 108; 152.

74 See also Art. 23[2[ of the Brazil-Colombia IIA and Annex 1, Art. 3 of the Brazil-Chile IIA.

75 See also Art. 16[4]f of Brazil-Colombia IIA and Art. 1[1] of the Annex of the Brasil-Chile IIA. that the constitution of the State-State tribunal is not impaired by inaction of the parties. ${ }^{76}$ The decision will be mandatory to the parties (Brazil-Mexico BIT, Art. 19.8 and Brazil-Peru Chapter, art. 2.21(10)). ${ }^{77}$ Moreover, the treaties most probably refer to the UNASUR Centre of Dispute Settlement, if it allows for SSIA in the future, which would replace some provisions on the constitution of arbitral tribunals (Brazil-Mexico BIT Art. 19.4 and Brazil-Peru Chapter, art. 2.21(5)). ${ }^{78}$

To conclude, the SSIA provisions in the Brazilian treaties with Latin American States provide for the possibility of declaratory awards in relation to a measure, by request of both home and host States. The treaties could have been clearer on the conferral of jurisdiction to State-State arbitration in relation to the interpretation and application of general provisions. When it comes to the possibility of a declaration of non-breach, this would be of less use here, given the absence of subsequent investor-state arbitration. There is some room for the consultations and negotiations and the SSIA is available to solve all pending issues, but the recourse to it is currently unrealistic. While host States are safe against the risks of investor-state arbitration, the lack of ISA provisions puts much pressure on internal domestic legal systems. Only time will reveal how reliable and effective the mechanism is.

\section{Final CONCLUSIONS}

To sum up, the article concludes that the possibility of SSIA is neither a backlash nor a more effective strategy compared to ISA. Jurisdiction clauses are generally broad enough to encompass all types of disputes of SSIA, including those brought by host States. It constitutes an additional opportunity for host States to advance their understanding of the treaties and balance the investment treaty commitments. In several situations, SSIA would be the only possible mechanism and in others, SSIA will be a complement to ISA. This adds important inputs to the interpretation process, enabling alternative litigation strategies for host States.

76 Cf. United States reluctance to appoint Chapter 20 panels in NAFTA State-State Arbitration.

77 See also Art. 23[12], Brazil-Colombia IIA; and Annex 1 Art. 7[4], Brazil-Chile IIA.

78 See also Art. 23[1], Brazil-Colombia IIA; and Annex 1 Art. 2[1], Brazil-Chile IIA. 
These developments have translated into alternative settlement mechanisms, into different BIT models or into more light-touch approaches. They are not necessarily more effective compared to classic ISA, but may be especially fit for host States. Anyway, SSIA may serve to remediate some of the shortcomings of international arbitration and to re-engage some States, which have opted out or remained at the margins of the legal development in the area.

While State-State arbitration may be a viable strategy, there are some challenges that need to be overcome. The definition of the term dispute, the obligation to consult on the meaning of provisions and the establishment of a clear hierarchy between State-State awards in relation to investor-State awards are some of the ways forward. Each of these aspects should be developed in treaty-making initiatives that wish bring new alternatives for host States.

\section{References}

Allen BE and Soave T, 'Jurisdictional Overlap in WTO Dispute Settlement and Investment Arbitration' in Jorge A Huerta-Goldman, Antoine Romanetti and Franz X Stirnimann (eds), WTO Litigation, Investment Arbitration and Commercial Arbitration (Kluwer Law International 2013)

Alschner W, 'The Return of the Home State and the Rise of "Embedded" Investor-State Arbitration' in Shaheeza Lalani and Rodrigo Polanco Lazo (eds), The Role of the State in Investor-State Arbitration (Brill 2014)

Antonopoulos C, Counterclaims before the International Court of Justice (TMC Asser Press 2011)

Bas M, 'América do Sul em face dos tratados bilaterais de investimento: rumo ao retorno do Estado na solução de controvérsias?' (2016) 13 Revista de Direito Internacional (Brazilian Journal of International Law) $<$ https://www.publicacoesacademicas.uniceub.br/rdi/ article/view/3944> accessed 1 October 2017

Berman F, 'The Relevance of the Law on Diplomatic Protection in Investment Arbitration' in British Institute of International and Comparative Law (ed), Investment treaty law: current issues. 2, Nationality and investment treaty claims ; Fair and equitable treatment in investment treaty law (British Institute of International and Comparative Law 2007)

Bernasconi-Osterwalder N, 'State-State Dispute Settlement in Investment Treaties' (International Institute for Sustainable Development 2014) <http://www.iisd. $\mathrm{org} / \mathrm{sites} /$ default/files/publications/best-practicesstate-state-dispute-settlement-investment-treaties.pdf $>$ accessed 23 July 2015

Burke-White WW, 'Argentine Financial Crisis: State Liability under BITs and the Legitimacy of the ICSID System, The' (2008) 3 Asian Journal of W'TO and International Health Law and Policy 199

Crawford J and Nevill P, 'Relations between International Courts and Tribunals: The "Regime Problem", Regime Interaction in International Law (CUP 2012)

Dolzer R and Schreuer CH, Principles of International Investment Law (2nd ed, OUP 2012)

García-Bolívar OE, 'Permanent Investment Tribunals: The Momentum Is Building Up' in Jean E Kalicki and Anna Joubin-Bret (eds), Reshaping the Investor-State Dispute Settlement System: Journeys for the 21st Century (Brill Nijhoff 2015)

Gaukrodger D, 'State-to-State Dispute Settlement and the Interpretation of Investment Treaties' (Organisation for Economic Co-operation and Development 2016) OECD Working Papers on International Investment <http://www.oecd-ilibrary.org/content/ workingpaper/5jlr71 rq1j30-en> accessed 1 October 2017 ICSID, Convention on the Settlement of Investment Disputes between States and Nationals of Other States (International Centre for Settlement of Investment Disputes 1968)

Ishikawa T, 'Keeping Interpretation In Investment Treaty Arbitration “on Track”: The Role of State Parties' in Jean E Kalicki and Anna Joubin-Bret (eds), Reshaping the Investor-State Dispute Settlement System: Journeys for the 21st Century (Brill Nijhoff 2015)

Levy D de A, Borja AG de and Pucci A (eds), Investment Protection in Brazil (Kluwer Law International 2014)

Lo C, 'Relations and Possible Interactions between State-State Dispute Settlement and Investor-State Arbitration under Bits' (2013) 6 Contemporary Asia Arbitration Journal 1

Lubambo M, 'Is State-State Investment Arbitration an Old Option to Latin America?' (2016) 34(2) Conflict Resolution Quarterly 225

Macías MJL, 'Looking Backwards to Inter-State Investment Dispute Settlement: Is There Space for Transparency?' (2016) forthcoming The Journal of World 
Investment \& Trade - Special Issue - The Latin American Challenge to the Current System of Investor-State Dispute Settlement

McIntyre J, 'Declaratory Judgments of the International Court of Justice', Hague Yearbook of International Law (Martinus Nijhoff 2012)

Monebhurrun N, Novelty in International Investment Law: The Brazilian Agreement on Cooperation and Facilitation of Investments as a Different International Investment Agreement Model' [2016] Journal of International Dispute Settlement

Orecki M, 'State-to-State Arbitration pursuant to Bilateral Investment Treaties: The Ecuador-US Dispute.' $<$ http://www.youngicca-blog.com/state-to-state-arbitration-pursuant-to-bilateral-investment-treaties-theecuador-us-dispute/> accessed 16 May 2015

Paparinskis M, 'Investment Arbitration and the Law of Countermeasures' (2009) 79 British Yearbook of International Law 264

__ ' 'Opinio Juris » Blog Archive HILJ Online Symposium: On the Love of Hybrids and Technicalities Opinio Juris' <http://opiniojuris.org/2014/03/31/ hilj-online-symposium-love-hybrids-technicalities / > accessed 16 May 2016

Paulsson J, 'Arbitration Without Privity' (1995) 10 ICSID Review - Foreign Investment Law Journal 232

Posner TR and Walter MC, 'The Abiding Role of StateState Engagement in the Resolution of Investor-State Disputes' in Jean E Kalicki and Anna Joubin-Bret (eds), Reshaping the Investor-State Dispute Settlement System: Journeys for the 21st Century (Brill Nijhoff 2015)

Potestà M, 'Republic of Italy v. Republic of Cuba' (2012) 106 AJIL 341

_- 'State-to-State Dispute Settlement Pursuant to Bilateral Investment Treaties: Is There Potential?' in Nerina Boschiero and others (eds), International Courts and the Development of International Law (T M C Asser Press 2013)

__ ' 'Towards a Greater Role for State-to-State Arbitration in the Architecture of Investment Treaties?' in Shaheeza Lalani and Rodrigo Polanco Lazo (eds), The Role of the State in Investor-State Arbitration (Brill 2014)

Recanati M, 'Diplomatic Intervention and State-to-State Arbitration as Alternative Means for the Protection of Foreign Investments and Host States' General Inte- rests: The Italian Experience' in Giorgio Sacerdoti and others (eds), General Interests of Host States in International Investment Law (CUP 2014)

Roberts A, 'Power and Persuasion in Investment Treaty Interpretation: The Dual Role of States' (2010) 104 AJIL 179

__ ' 'Opinio Juris » Blog Archive HILJ Online Symposium: Anthea Roberts Responds to Martins Paparinskis - Opinio Juris' <http://opiniojuris.org/2014/03/31/ hilj-online-symposium-anthea-roberts-responds-martins-paparinskis/> accessed 16 May 2016

_-, 'State-to-State Investment Treaty Arbitration: A Hybrid Theory of Interdependent Rights and Shared Interpretive Authority' (2014) 55 Harvard International Law Journal 1

Sacerdoti G and others (eds), General Interests of Host States in International Investment Law (CUP 2014)

Sacerdoti G and Recanati M, 'Approaches to Investment Protection outside of Specific International Investment Agreements and Investor-State Settlement' in Marc Bungenberg and others (eds), International Investment Law (Nomos ; Hart 2015)

Titi C, 'Investment Arbitration in Latin America' (2014) 30 Arbitration International 357

'International Investment Law and the Protection of Foreign Investment in Brazil' Transnational Dispute Management <http://www.transnational-disputemanagement.com/journal-advance-publication-article. asp?key $=592>$ accessed 15 May 2015

Trevino CJ, 'State-to-State Investment Treaty Arbitration and the Interplay with Investor-State Arbitration Under the Same Treaty' (2014) 5 Journal of International Dispute Settlement 199

UNCTAD, 'World Investment Report' (United Nations 2015) UNCTAD/WIR/2015

Vandevelde KJ, Bilateral Investment Treaties: History, Policy and Interpretation (OUP 2010)

Wong J, 'The Subversion of State-to-State Investment Treaty Arbitration' (2014) 53 Columbia Journal of Transnational Law 6

Wyler E and Papaux A, 'The Different Forms of Reparation: Satisfaction' in James Crawford, Alain Pellet and Simon Olleson (eds), The law of international responsibility (OUP 2010) 
Para publicar na Revista de Direito Internacional, acesse o endereço eletrônico www.rdi.uniceub.br ou www.brazilianjournal.org.

Observe as normas de publicação, para facilitar e agilizar o trabalho de edição. 